\title{
Shelf recruitment of Calanus finmarchicus off the west coast of Norway: role of physical processes and timing of diapause termination
}

\author{
Annette Samuelsen ${ }^{1, *}$, Geir Huse $^{2}$, Cecilie Hansen ${ }^{1}$ \\ ${ }^{1}$ Nansen Environmental Remote Sensing Center, Thormoehlensgate 47, 5006 Bergen, Norway \\ ${ }^{2}$ Institute of Marine Research, Box 1870, Nordnes, 5817 Bergen, Norway
}

\begin{abstract}
The copepod Calanus finmarchicus is an important part of the Norwegian Sea ecosystem because of its dominating abundance and importance as prey for fish larvae and adult planktivorous fish. The abundance of $C$. finmarchicus on the Norwegian shelf is generally low in winter, whereas in spring the shelf is replenished by individuals that overwinter at depth, either in fjords or in the deep basins of the Norwegian Sea. In the present study shelf recruitment is investigated using an individual-based model for C. finmarchicus coupled to the HYbrid Coordinate Ocean Model and a biophysical model. The model was set up on a nested grid along the west coast of Norway and used to study the shelf recruitment originating from the Norwegian Sea. We investigate the effect of wind, currents and the timing of Calanus ascent on the shelf abundance of C. finmarchicus. The most important findings are the following: (1) periods of large on-shelf transport are connected with strong westerly winds associated with passing low-pressure systems; (2) the transport of overwintering adults onto the shelf determines the total shelf abundance prior to mid-summer; (3) the early spring bloom on the shelf causes increased shelf population of $C$. finmarchicus in the spring and throughout the summer compared to the areas further off-shore; and (4) the entry routes taken by C. finmarchicus are related to bathymetry; in particular, the deep trenches around Halten Bank and the Norwegian trench are favoured places to enter the Norwegian shelf.
\end{abstract}

KEY WORDS: Cross-shelf transport $\cdot$ Calanus $\cdot$ Diapause $\cdot$ Norwegian Sea $\cdot$ Herring recruitment

\section{INTRODUCTION}

The calanoid copepod Calanus finmarchicus is a key zooplankton species in the NE Atlantic. It is highly abundant in the area and acts as an important link between phytoplankton production and the higher trophic levels (Sundby 2000, Melle et al. 2004). The young stages of $C$. finmarchicus serve as food for fish larvae and young fish, while the older stages serve as food for adult planktivorous fish such as herring and mackerel. Its life cycle includes overwintering at depth in the deep basins of the Norwegian Sea or in fjords. The copepodites of Stages 4 and 5 descend to their overwintering depth at 400 to $1400 \mathrm{~m}$ during summer (Heath et al. 2000, Halvorsen et al. 2003). Prior to de- scending, the copepods store fat, and this makes it a particularly nutritious food source. Individuals that descend over the shelf will have a shallower overwintering depth and thus suffer a higher predation from visual predators than individuals that overwinter in the deep dark basins and fjords (Bagøien et al. 2001). The shelf abundance is therefore low during winter (Halvorsen et al. 2003), but is replenished each spring with individuals from outside the shelf. C. finmarchicus do not swim very fast compared to the horizontal currents; thus, shelf recruitment is primarily a result of physical processes (Backhaus et al. 1994, Heath et al. 1999). By far the largest overwintering biomass of C. finmarchicus is in the Norwegian Sea, but the fjord populations may be an important source for the shelf 
population largely because of their 'direct access' to the Norwegian Coastal Current (NCC) and earlier reproduction (Rey 2004). In the present paper we focus on the C. finmarchicus in the Norwegian Sea and disregard the fjords. The shelf recruitment of $C$. finmarchicus can be separated into individuals that are transported from the open ocean to the shelf and new individuals that are produced on the shelf. It is presently unknown which of these is most important in determining the abundance of different stages of $C$. finmarchicus on the shelf.

In studies of fish recruitment, much attention has been given to the importance of the timing of fish spawning in relation to the peak in nauplius abundance, motivated by the so-called match-mismatch hypothesis (Ellertsen et al. 1989, Cushing 1990). This hypothesis postulates that the survival of fish larvae is related to a match in the timing of occurrence of larvae and their food. The largest egg production rate in Calanus finmarchicus occurs during the spring bloom (Niehoff et al. 1999, Stenevik et al. 2007); consequently, the timing of the spring bloom influences nauplius abundance. The spring bloom occurs a month later in the Norwegian Sea compared to the shelf areas at similar latitudes, due to the early stratification of the coastal water (Rey 2004), and growth conditions for C. finmarchicus therefore vary strongly with time, depending on whether they are found on or off the shelf. The main spawning grounds for the Norwegian springspawning (NSS) herring Clupea harengus are on the shelf along western Norway (Fig. 1), and the growth and survival of the larvae are likely to depend on the food availability there. Therefore, processes related to transport onto the shelf and recruitment of Calanus finmarchicus on the shelf may help explain parts of the considerable recruitment variability in the NSS herring stock (Toresen \& Østvedt 2000, Sætre et al. 2002).

The Norwegian shelf has a complex bathymetry, and earlier field and modelling studies have shown that transport from the Norwegian Sea onto the Norwegian shelf is spatially variable (Sundby 1984, Slagstad \& Tande 1996). Several trenches are hypothesized to facilitate the on-shelf transport of Calanus finmarchicus, and modelling studies have shown that there are zones with cross-shelf currents in the upper waters (Slagstad \& Tande 1996, Vikebø et al. 2005), but the locations of the main pathways between the Norwegian Sea and the Norwegian shelf remain unknown.

A previous study of Calanus finmarchicus in the Norwegian Sea with a coarser grid $(\sim 20 \mathrm{~km})$ showed very little cross-shelf transport of individuals (Torgersen \& Huse 2005), and this was thought to be a problem related to the grid resolution. In the present study, we used a grid resolution of $4.5 \mathrm{~km}$. It is computationally very demanding to run the model with this resolution over a large area, but the role of advection on these

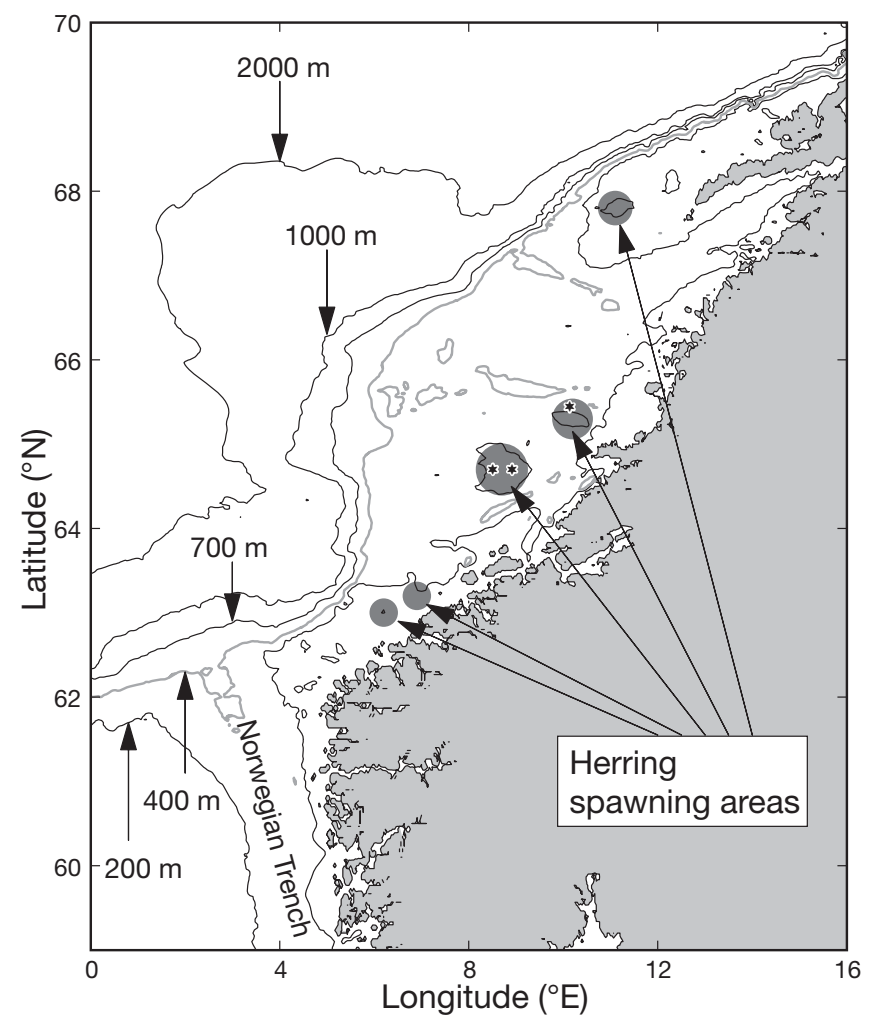

Fig. 1. Bathymetry off western Norway. The shelf is relatively wide $(>100 \mathrm{~km})$, but becomes narrower around $63^{\circ} \mathrm{N}$ and north of $68^{\circ} \mathrm{N}$. Deep trenches incise the shelf topography in some places. Calanus finmarchicus overwinter in the deep areas $(>500 \mathrm{~m})$ off the shelf and some overwinter in the Norwegian Trench. Grey circles show the spawning areas of the Norwegian spring-spawning herring; those marked with stars are the Sklinna Bank $\left({ }^{*}\right)$ and Halten Bank $\left({ }^{* *}\right)$

individuals makes a basin-wide model necessary. Therefore, we have adopted a nested approach, with a coarse $16 \mathrm{~km}$ model grid covering the North Sea and Norwegian Sea and a $4.5 \mathrm{~km}$ model grid along the west coast of Norway (Fig. 2). The HYbrid Coordinate Ocean Model (HYCOM; Bleck 2002) was coupled to a biogeochemical model, the NORWegian ECOlogical Model system (NORWECOM; Skogen et al. 1995, Skogen \& Søiland 1998) and an individual-based model for C. finmarchicus (CFIBM) and run in this nested configuration. Here we use the coupled model system to investigate shelf recruitment of $C$. finmarchicus from the Norwegian Sea. The mechanisms determining the timing of the ascent in C. finmarchicus are still uncertain (Speirs et al. 2005); therefore, in 3 of the model runs the 'wake-up day' has been systematically altered. We focus on the timing of peak abundance on the shelf in relation to the spring ascent of $C$. finmarchicus, temporal and spatial variability in on-shelf transport, and the relative importance of on-shelf transport and local reproduction for the shelf abundance of C. finmarchicus. 


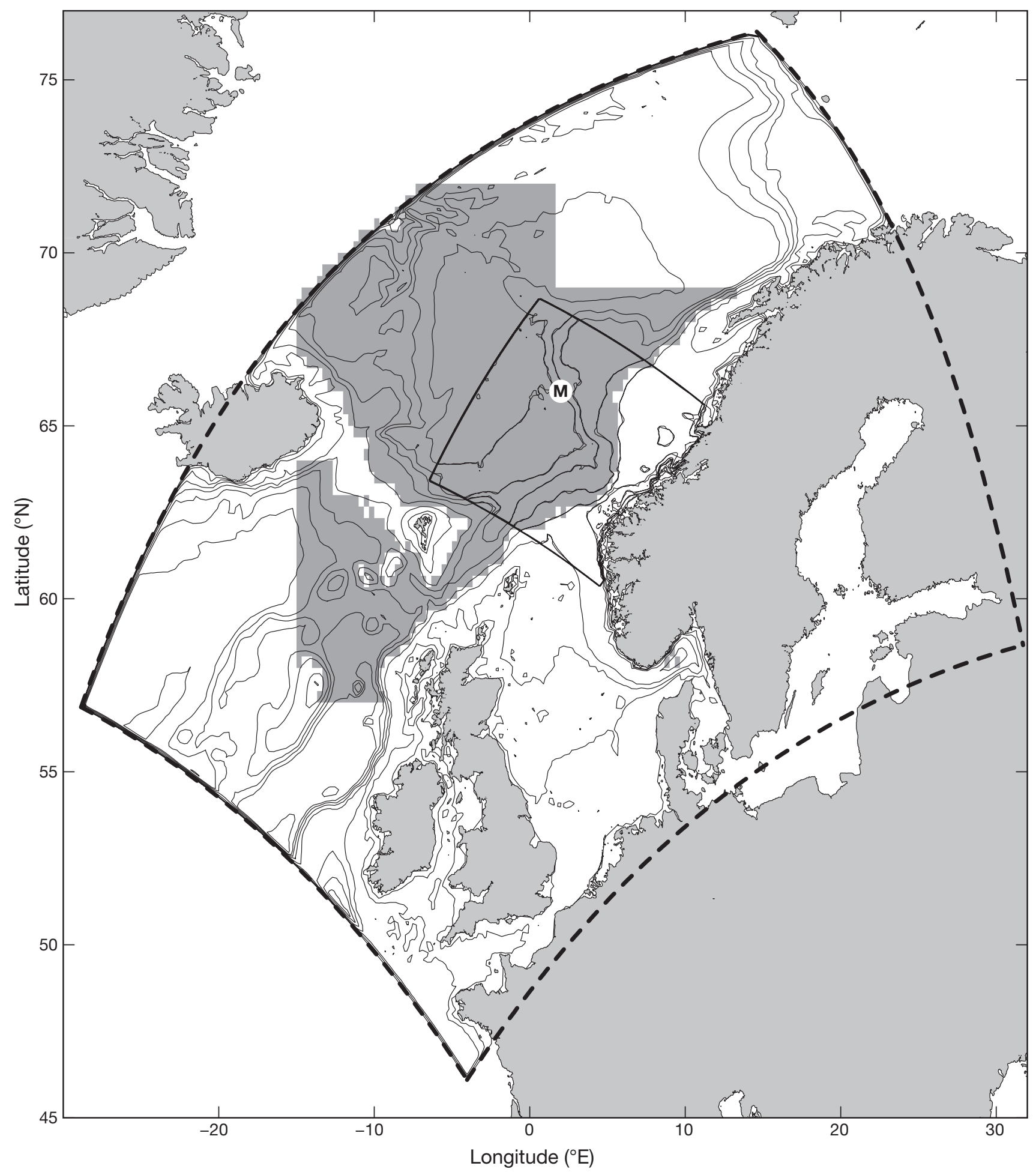

Fig. 2. Model domains of the 2 smallest grids in the nested system. The grid covering the Norwegian Sea and North Sea has a resolution of about $16 \mathrm{~km}$, and the smallest grid has a resolution of about $4.5 \mathrm{~km}$. Both model grids are used in the Calanus finmarchicus simulation; the individuals from the outer model domain can enter the inner model domain. The nesting of the physical variables is also 1-way from the large model to the small model. Dark grey shading indicates the area where the overwintering population was initiated. Some areas have no individuals, either because the areas are too shallow to host overwintering individuals (southern part of the domain) or because previous runs showed that no individuals were advected into the small model domain from these areas (northern part of the domain). M: location of Station M 


\section{MATERIALS AND METHODS}

Model description. Circulation model: HYCOM was set up in a 3-model grid, nested configuration. All the nesting was 1-way, i.e. the outer model domain provided boundary conditions for the inner model domain. All 3 models were forced with the ERA-40 6-hourly reanalysis fields (Uppala et al. 2005) and climatological river runoff (Dumenil et al. 1993, Dai \& Trenberth 2002). The largest model domain covers the North Atlantic and Arctic Ocean and has its southern boundary at $30^{\circ} \mathrm{S}$. Because this model domain contains the Arctic, it includes an ice module. This module consisted of 2 components: a thermodynamic model (Drange \& Simonsen 1996) and a dynamic model using the elastic-viscous-plastic rheology (Hunke \& Dukowicz 1997). This model was spun up from the Generalized Digital Environmental Model Climatology (Teague et al. 1990) in 1958 to the initial time of simulation (beginning of 1995). The drift in temperature, salinity and transport was checked and found to be small. The temperature and salinity had drifts of 1.5 and $-0.04 \%$, respectively, over 10 yr. This model provided boundary conditions to the middle model domain, which covers the Norwegian Sea and the North Sea (Fig. 2). The middle model domain has a grid resolution of $16 \mathrm{~km}$ and was initiated from interpolated fields from the North Atlantic model and run from 1990 (Table 1). The inner model has a grid resolution of $4.5 \mathrm{~km}$ and covers the shelf, shelf-slope and deep ocean off western Norway (Fig. 2). This model was started with interpolated fields from the middle model on Day 135 of $1994 ; 0.5 \mathrm{yr}$ of spin-up is sufficient when initialized from the medium model. A summary of the model spin-up is given in Table 1 .

Biogeochemical model: HYCOM was coupled to the biogeochemical model NORWECOM, hereafter HYCOM-NORWECOM. NORWECOM contains 2 phytoplankton functional groups (diatoms and flagellates), 3 nutrients (phosphate, nitrate and silicate), detritus, biogenic silica and oxygen. The model does not include zooplankton, but grazing is implicitly

Table 1. Overview of model runs and spin-up

\begin{tabular}{|lccc|}
\hline Model & $\begin{array}{c}\text { Grid size } \\
(\mathrm{km})\end{array}$ & \multicolumn{2}{c|}{ Initiation time- } \\
\cline { 3 - 4 } & 50 & 1958 & 1987 \\
\hline $\begin{array}{c}\text { Atlantic and } \\
\text { Arctic Ocean }\end{array}$ & & 1990 & 1993 \\
$\begin{array}{c}\text { North Sea and } \\
\text { Norwegian Sea }\end{array}$ & 16 & Biogeochemical \\
$\begin{array}{c}\text { Western coast } \\
\text { of Norway }\end{array}$ & 4.5 & 1994, & 1994, \\
Day 134 & Day 134 \\
\hline
\end{tabular}

included through a constant mortality rate. A shorter spin-up period was used for the biogeochemical model than for the physical model (Table 1). Growth of phytoplankton and regeneration of nutrients is a relatively fast process; this part of the model therefore needed a shorter time to become equilibrated. NORWECOM was initiated in the Atlantic model in 1987 with nutrients from the Levitus climatology (Conkright et al. 1998) and constant values for the other variables (diatoms, flagellates and detritus were $0.1 \mathrm{mg} \mathrm{N} \mathrm{m}^{-3}$, biogenic silica was $0.1 \mathrm{mg} \mathrm{Si} \mathrm{m^{-3 }}$ and oxygen was $4300 \mathrm{mg} \mathrm{O} \mathrm{m}^{-3}$ ). The nutrients were checked for drift, and silicate, nitrate and phosphate had a drift of -1.72 , 0.51 and $-0.56 \%$, respectively, over the period from 1990 to 1994. As with the physical model, HYCOMNORWECOM in the 2 smaller models was initialized with interpolated fields from the 2 larger models, and boundary conditions were also provided from the larger models. The $16 \mathrm{~km}$ model was run with the biogeochemical model from 1990, and the $4.5 \mathrm{~km}$ model was run as a coupled model from Day 134 in 1994 (Table 1). Daily averaged fields of diatom carbon concentration were used as food input to the CFIBM; the modelled diatom concentration was converted from units of nitrate to milligrams of carbon per cubic metre using a Redfield ratio of $6.62 \mathrm{~mol} \mathrm{C} \mathrm{mol}^{-1} \mathrm{~N}$. Flagellates were not used because copepods prefer diatoms over flagellates as their food source (Meyer-Harms et al. 1999, Irigoien et al. 2003).

Individual-based Calanus model: $\mathrm{HYCOM}$ has an online particle-tracking code built into the model, and this was used to track the positions of Calanus finmarchicus. This particle-tracking routine is an extended version of the routine developed for the Miami Isopycnic Coordinate Ocean Model (Garraffo et al. 2001). Horizontal interpolation of the model velocities is performed using 2-dimensional polynomial interpolation on a 16-point grid box surrounding the particle. If 16 ocean grid points are not available, bilinear interpolation is used. The temporal interpolation is performed using a fourth-order Runge-Kutta algorithm. The particle-tracking routine takes into account both horizontal and vertical velocity in the floats movement, but most of the vertical positioning is decided by the vertical behaviour of C. finmarchicus, which is determined in the CFIBM. The time step for the particle-tracking code was set to $48 \mathrm{~min}$ in the medium-resolution model and $16 \mathrm{~min}$ in the high-resolution model; this is 4 times the baroclinic time step of the model in both cases. The tracks were estimated using instantaneous velocities.

The CFIBM takes into account growth, mortality and reproduction of Calanus finmarchicus (Huse 2005, Torgersen \& Huse 2005). It includes 13 developmental stages: egg, 6 nauplius stages (N1 to N6), 5 copepodite 
stages (C1 to $\mathrm{C} 5)$ and 1 adult stage (C6). Because of the great abundance of individuals in the C. finmarchicus population, it is not feasible to simulate each individual separately. The population is therefore simulated using a super-individual approach (Scheffer et al. 1995), where 1 particle in the physical model represents 1 super-individual. Each super-individual represents a dynamic number of individuals with identical properties, described by a strategy vector (Huse et al. 1999, Huse 2001) and an attribute vector (Table 2) (Chambers 1993, Carlotti \& Wolf 1998, Huse et al. 1999). The time step used in CFIBM is $1 \mathrm{~h}$.

Vertical migration: The diapause behaviour is controlled by 3 elements in the strategy vector: wake-up day (WUD), fat/soma ratio (FSR) and allocation-to-fat day (AFD), as determined by Fiksen (2000) (Table 2). WUD gives the day on which the spring ascent is initiated. The ascent rate of Calanus finmarchicus is variable between individuals (Heath 1999), attributed in part to vertical differences in buoyancy due to the compressibility of the fat sac of the overwintering C. finmarchicus (Visser \& Jonasdottir 1999). In order to simplify the model, we assumed a constant ascent and descent speed of $20 \mathrm{~m} \mathrm{~d}^{-1}$ (Heath 1999). The overwintering C5 are assumed to mature to adults upon entering the upper mixed layer, which was fixed at $40 \mathrm{~m}$ in the simulations. When the new generation moult to Stage C5, they have a choice between reproducing or preparing for overwintering in diapause and spawning the following spring. This choice is implemented so that individuals that become C5 before AFD continue

Table 2. Strategy and attribute vectors and their base values, as used in the individual-based Calanus finmarchicus model. Superscripts indicate sources for values

\begin{tabular}{|c|c|c|}
\hline Description & Abbrev. & Value \\
\hline \multicolumn{3}{|l|}{ Strategy vectors } \\
\hline Starting day for spring migration to the surface $\mathrm{a}^{\mathrm{a}}$ & WUD & 35 \\
\hline Fat/soma ratio needed before descending to diapause ${ }^{b}$ & FSR & 0.4 \\
\hline Initial day of allocation to fat in copepodite Stage $5^{\mathrm{b}}$ & AFD & 144 \\
\hline Overwintering depth ${ }^{\mathrm{c}}$ & OWD & $800.0 \pm 300 \mathrm{~m}$ \\
\hline Minimum daytime depth of copepodites ${ }^{\mathrm{d}}$ & VM1 & $13 \mathrm{~m}$ \\
\hline Size dependence of daytime depth of copepodites ${ }^{d}$ & VM2 & 20500 \\
\hline \multicolumn{3}{|l|}{ Attribute vectors } \\
\hline Stage (0: egg; 1-6: nauplii; 7-11: copepodites; 12 : adult) & ) STA & 12 \\
\hline Number of individuals in a super-individual & NIN & $1.0 \times 10^{12}$ \\
\hline Carbon content per individual & WST & $120 \mu \mathrm{g} \mathrm{C}$ \\
\hline Age & AGE & $150 \mathrm{~d}$ \\
\hline Fat content per individual & WFA & $20 \mu \mathrm{g} \mathrm{C}$ \\
\hline Flag for vertical migration & MIG & Diapause \\
\hline \multicolumn{3}{|c|}{$\begin{array}{l}\text { a Heath et al. (1999), who report emergence between Day } 40 \text { and } 110 \\
{ }^{b} \text { Fiksen (2000) }\end{array}$} \\
\hline \multicolumn{3}{|l|}{${ }^{\mathrm{c} E d v a r d s e n ~ e t ~ a l . ~(2006) ~}$} \\
\hline${ }^{\mathrm{d} D a l e} \&$ Kaartvedt (2000) & & \\
\hline
\end{tabular}

to reproduce within the season, whereas after this day individuals that enter the C5 stage start to allocate surplus energy to storage. The descent to the overwintering depth (OWD; Table 2) is initiated when the fat/soma ratio of the individual is greater than FSR (Table 2). At night, all individuals were assumed to stay at the depth of maximum food availability. Stages N3 to N6, C1 and C2 remain at this depth all the time, while the Stages C3 to C6 perform diurnal migration, where the daytime depth $\left(Z_{\text {daytime }}\right)$ is calculated from VM1, VM2 (Table 2) and the size of the individuals:

$$
Z_{\text {daytime }}=\mathrm{VM} 1+\mathrm{VM} 2 \cdot \text { size }
$$

where size is in metres and is calculated according to Carlotti \& Wolf (1998):

$$
\text { size }=0.001 \cdot \mathrm{cm} 1 \cdot(\mathrm{WST}+\mathrm{WFA})
$$

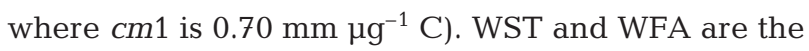
structural weight and fat content of the individuals, respectively (Table 2). Thus, the amplitude in vertical migration increases with increasing size. VM1 and VM2 are adjusted so that Stage C3 individuals descend to $30 \mathrm{~m}$ depth and adults migrate to about $60 \mathrm{~m}$ depth during daytime (Dale \& Kaartvedt 2000). Daytime was defined as surface-light intensities $>8 \mu \mathrm{E} \mathrm{m} \mathrm{m}^{-2}$ $\mathrm{s}^{-1}$. Eggs and Stages N1 and N2 move randomly up and down if they are within the mixed layer and sink if they are below the mixed layer; in this case the mixed-layer depth is calculated from HYCOM.

Stage development: Calanus finmarchicus do not start feeding until Stage N3; therefore, stage duration for eggs, N1 and N2 is temperature ( $T$ ) dependent and calculated according to the Belehrádek equation:

$$
D_{i}(T)=a(T+9.11)^{-2.05}
$$

where $D_{i}(T)$ is the development time (in days) from one stage to another. The values for the stage-dependent parameter $a$ are those from Lynch et al. (1998). For the feeding stages, a critical-weight criterion is used to determine the transition between stages (Carlotti \& Wolf 1998). Thus, an individual develops into the next stage when its weight is above a stage-specific threshold (Table 3).

Mortality: The mortality was taken from stage-specific estimates for the target region. The nauplius mortalities are $0.3 \mathrm{~d}^{-1}$ for eggs, $0.15 \mathrm{~d}^{-1}$ for N1, $0.10 \mathrm{~d}^{-1}$ for N2 and $0.02 \mathrm{~d}^{-1}$ for N3 to N6. The copepodite mortality was $0.025 \mathrm{~d}^{-1}$ for C1, $0.02 \mathrm{~d}^{-1}$ for C2 and C3, $0.025 \mathrm{~d}^{-1}$ for $\mathrm{C} 4$ and $0.03 \mathrm{~d}^{-1}$ for C5 and C6 (Ohman et al. 2004). The mortality during dia- 
Table 3. Essential parameters and their values, as used in the individualbased Calanus finmarchicus model. Superscripts indicate sources for values

\begin{tabular}{|c|c|c|}
\hline Description & Abbrev. & Value \\
\hline Maximum number of super-individuals & mpop & 90000 \\
\hline $\begin{array}{l}\text { Maximum number of super-individuals } \\
\text { that can be produced in } 1 \text { time step }\end{array}$ & offsp & 22500 \\
\hline Minimum carbon content for maturation & cmat & $100 \mu \mathrm{g} \mathrm{C}$ \\
\hline Clutch size & Cs_cal & 40 eggs \\
\hline Egg weight & eggw & $0.23 \mu \mathrm{g} \mathrm{C}$ \\
\hline Diffuse light attenuation rate & diff_cal & $0.1 \mathrm{~m}^{-1}$ \\
\hline Light loss through surface & ksur & 0.5 \\
\hline $\mathrm{C}: \mathrm{N}$ Redfield ratio & red & 6.62 \\
\hline $\begin{array}{l}\text { Individuals only reproduce when } \\
\text { shallower than this depth }\end{array}$ & mld & $50 \mathrm{~m}$ \\
\hline $\begin{array}{l}\text { Maximum growth rate: } \\
\text { Stages N3-N6 } \\
\text { Stages C1-C5 and adults }\end{array}$ & $\operatorname{imax}$ & $\begin{array}{l}0.53 \mathrm{~d}^{-1} \\
0.43 \mathrm{~d}^{-1}\end{array}$ \\
\hline Temperature coefficient for grazing ${ }^{a}$ & $\mathrm{Q}_{10}$ & 2.1 \\
\hline Weight-related scaling parameter ${ }^{a}$ & AW & 0.8 \\
\hline $\begin{array}{l}\text { Ivlev grazing constant }{ }^{\mathrm{b}} \text { : } \\
\text { Stages N3-N6 } \\
\text { Stages C1-C5 and adults }\end{array}$ & Iv & $\begin{array}{l}0.0324 \mathrm{mg} \mathrm{C}^{-1} \mathrm{~m}^{3} \\
0.0219 \mathrm{mg} \mathrm{C}^{-1} \mathrm{~m}^{3}\end{array}$ \\
\hline Temperature coefficient for respiration ${ }^{a}$ & $\mathrm{Q}_{\mathrm{R} 10}$ & 3.4 \\
\hline Coefficients for respiration ${ }^{a}$ : & $\begin{array}{l}r_{1} \\
r_{2}\end{array}$ & $\begin{array}{l}0.01 \mathrm{~d}^{-1} \\
0.2 \mathrm{~d}^{-1}\end{array}$ \\
\hline $\begin{array}{l}\text { Critical weight for stage development }{ }^{\mathrm{a}} \text { : } \\
\text { Moulting: N2 - N3 } \\
\text { Moulting: N3 - N4 } \\
\text { Moulting: N4 - N5 } \\
\text { Moulting: N5 - N6 } \\
\text { Moulting: N6 - C1 } \\
\text { Moulting: C1 - C2 } \\
\text { Moulting: C2 - C3 } \\
\text { Moulting: C3 - C4 } \\
\text { Moulting: C4 - C5 } \\
\text { Moulting: C5 - Adult } \\
\text { Critical adult weight }\end{array}$ & & $\begin{array}{c}0.05 \mu \mathrm{g} \mathrm{C} \\
0.20 \mu \mathrm{g} \mathrm{C} \\
0.30 \mu \mathrm{g} \mathrm{C} \\
0.45 \mu \mathrm{g} \mathrm{C} \\
0.75 \mu \mathrm{g} \mathrm{C} \\
1.10 \mu \mathrm{g} \mathrm{C} \\
2.50 \mu \mathrm{g} \mathrm{C} \\
7.00 \mu \mathrm{g} \mathrm{C} \\
15.00 \mu \mathrm{g} \mathrm{C} \\
40.00 \mu \mathrm{g} \mathrm{C} \\
90.00 \mu \mathrm{g} \mathrm{C}\end{array}$ \\
\hline
\end{tabular}

the parent (mother) super-individual, is produced. The number of individuals in the new super-individual is a product of the clutch size (cs_cal; Table 3) and the number of individuals in the parent super-individual (NIN; Table 2). If there is fat left upon reaching the surface after diapause, the individuals can spawn prior to the spring bloom; otherwise, they must wait until the food availability is sufficient to allow for reproduction. Egg production is limited to 800 eggs individual ${ }^{-1}$ after which the individual is assumed to be exhausted and removed from the simulation (Carlotti \& Wolf 1998).

Growth: The individuals are assumed to feed only on diatoms (from the HYCOM-NORWECOM model, see above), although Calanus finmarchicus is known to also feed on other phytoplankton types (Meyer-Harms et al. 1999), as well as microzooplankton, and even on their own young (Ohman et al. 2004). Ingestion $(I)$ is regulated both by temperature and the availability of food (Campbell et al. 2001). The ingestion parameterization utilized the bioenergetics model of Carlotti \& Wolf (1998), except that the functional response was based on Campbell et al. (2001). The expression is:

$I=\operatorname{imax} \cdot \mathrm{Q}_{10}^{T / 10} \cdot \mathrm{WST}^{\mathrm{AW}} \cdot[1-\exp (-\mathrm{Iv} \cdot$ phyto $)]$

where $\mathrm{Q}_{10}$ and $\mathrm{AW}$ are the same as in Carlotti $\&$ Wolf (1998). $T$ is the temperature (in ${ }^{\circ} \mathrm{C}$ ) and phyto is the phytoplankton concentration (in $\mathrm{mg} \mathrm{C} \mathrm{m}^{-3}$ ). The parameters imax and $\mathrm{Iv}$ (Table 3) were fitted to the values in Campbell et al. (2001) and are different for nauplii and copepodites. The maximum growth rate, imax, had to be increased by a factor of 1.5 from the values obtained by Campbell et al. (2001), in order for the model results to fit the observed data. The observed data used were a

pause and migrating to and from their overwintering depth was $0.001 \mathrm{~d}^{-1}$ (Fiksen 2000). These mortality rates include all sources of mortality. In addition, $50 \%$ of the super-individuals die upon developing into mature individuals after the termination of diapause, simulating that males die shortly after the first spawning (Hirche 1996b). Mortality may also occur as a result of starvation. This was implemented so that individuals suffer a $10 \%$ daily mortality if their weight goes below $90 \%$ of the stage-specific moulting weight.

Spawning: Spawning occurs for adult individuals when they reach a certain weight (cmat; Table 3 ) and have allocated enough fat to produce a batch of eggs (cs_cal; Table 3). Once this criterion is fulfilled, a new super-individual, which inherits the strategy vector of stage-resolved time series from the Ocean Weather Station $\mathrm{M}$ that was taken in 1997 . Respiration $(R)$ is dependent on temperature and structural weight, such that:

$$
R=r_{1} \cdot \mathrm{WST}^{\mathrm{AW}} \cdot \mathrm{Q}_{\mathrm{R} 10}^{T / 10}+r_{2} I
$$

where $r_{1}, r_{2}$ and $\mathrm{Q}_{\mathrm{R} 10}$ are constants (Table 3) and the remaining components are defined as in Eq. (4). Egestion $(F)$ is a constant fraction of ingestion, such that:

$$
F=\lambda I
$$

where the assimilation efficiency, $\lambda$, is 0.7 (Carlotti \& Wolf 1998). The growth $(G)$ is then the ingestion minus respiration and egestion:

$$
G=I-R-F
$$


Experimental setup. In order to investigate the effect of diapause timing and food availability on the shelf recruitment, 5 different simulation experiments were set up (Table 4). In the first 3, the wake-up day was altered (WUD15, WUD35 and WUD55). Because it is unlikely that all individuals emerge from diapause on exactly the same day, each run had a 30 day spread around the central wake-up day. For example, in WUD35, an individual was equally likely to start emerging from diapause on any day between 20 and 50 (as indicated by the plus/minus values in Table 4). In the fourth experiment, the food concentration in each vertical model layer was horizontally averaged each day so that the time difference between the onshelf and off-shelf spring bloom was removed (UNIFOOD). The fifth experiment investigated the effect of reducing the allocated overwintering fat reserve and thus reducing the amount of pre-bloom spawning (LESSFAT). We used the run with the central wake-up day on Day 35 (WUD35) as the reference; all other runs have 1 parameter or growth condition altered from this run.

Each run was started at the beginning of 1995 and was run for $1 \mathrm{yr}$. Because of the strength and persistence of both the NCC and the Norwegian Atlantic Current (NAC), which flow through the area, many individuals will be transported both in and out of the inner model domain. The NAC carries relatively warm and saline Atlantic water into the Norwegian Sea and has a transport of about 4.2 Sv (Orvik et al. 2001). This boundary problem is solved by running the Calanus finmarchicus model in the medium-sized model as well. The individuals that are within the model domain of the inner model grid are saved to a file once a day. This file is read by the inner model, and individuals that have entered the inner model domain during the previous $24 \mathrm{~h}$ will be added to the population. The model was initialized on January 1, and the individual density was between 10000 and 30000 individuals $\mathrm{m}^{-2}$ (Fig. 2) (Heath et al. 2000, Edvardsen et al. 2006). Ini-

Table 4. The 5 different model runs used in the present paper. Plus/minus values indicate individual spread for wake-up day (WUD)

\begin{tabular}{|ll}
\hline Abbrev. & Description \\
\hline WUD15 & WUD is Day $15 \pm 15$, other parameters are kept at base values \\
WUD35 & WUD is Day $35 \pm 15$, other parameters are kept at base values \\
WUD55 & WUD is Day $55 \pm 15$, other parameters are kept at base values \\
UNIFOOD & $\begin{array}{l}\text { Food availability is spatially averaged over the inner model } \\
\text { domain for each day so that the food availability is the same on } \\
\text { the shelf and off-shore. WUD is Day } 35 \pm 15 \text {, other parameters } \\
\text { are kept at base values } \\
\text { Initial fat reserve (WFA; Table 2) is reduced from } 20 \text { to } 10 \mu g \text { C. }\end{array}$ \\
& WUD is Day $35 \pm 15$, other parameters are kept at base values
\end{tabular}

tially there were 20000 super-individuals in the outer model domain, 5147 of these were in the inner model domain. The individuals were initialized at depths between 500 and $1100 \mathrm{~m}$. Initially, the population consisted entirely of Stage C5 individuals; the initial carbon content and fat reserve is given in Table 2 .

\section{RESULTS \\ Validation}

The physical model was compared to >18000 measurements of temperature and salinity from the year 1995 in the region of the inner $(4.5 \mathrm{~km})$ model. The comparison shows that that model performs well for both temperature and salinity. The root mean square error (RMSE) for temperature is $1.6^{\circ} \mathrm{C}$, and the model temperature has a warm bias of overall $10 \%$, which is largest between 300 and $500 \mathrm{~m}$. The RMSE for salinity is 0.35 , and there is no bias in the salinity. The largest salinity errors occurred close to the coast, because climatological river runoffs were used, and, in 1995, the waters close to the coast were generally more saline in the model than in observations. There were also large errors in the frontal zone between the NCC and NAC; the exact location of this front is difficult to model, unless data assimilation is used. The mean transport in the NCC (water with salinity <34.9) was $0.6 \mathrm{~Sv}$ in the $4.5 \mathrm{~km}$ model. In the literature, we found that the transport in the NCC was estimated at $0.7 \mathrm{~Sv}$ (Björk et al. 2001); however, this estimate was based on data from northern Norway, outside the model domain. We were unable to find any estimates of the volume transport in the NCC inside the model domain. Volume transport into the area was calculated from the Atlantic model and was a 40 yr mean. The transport between Iceland and the Faeroe Islands was 2.4 Sv northward and between the Faeroe Islands and Scotland it was 3.4 Sv northward. Hansen \& Østerhus (2000) estimate the transport through these sections to be 3.3 and $3.7 \mathrm{~Sv}$, respectively. Therefore, the model's transport estimates into the Norwegian Sea are realistic, though slightly low.

The coupled model, HYCOM-NOR WECOM, was also compared to measurements of nutrients (about 4000) and chlorophyll (about 2500). Because the modelled phytoplankton concentration was the variable that influenced the simulated population of Calanus finmarchicus, we will focus on the chlorophyll. The model reproduces the annual cycle of phytoplankton with low winter 
concentrations, followed by high concentrations during the spring bloom and moderate summer concentrations (Fig. 3). The modelled spring bloom is about $14 \mathrm{~d}$ later than the spring bloom in the observations, while the simulated summer chlorophyll concentrations are reasonable. The delay in the spring bloom was caused by an overestimation of mixing in the physical model that delayed the shoaling of the mixed layer in the spring. Different mixing parameterizations have been tested to alleviate this problem, but none succeeded in producing an earlier spring bloom. We judged these model results to be good enough to use in the $C$. finmarchicus simulation as long as the delay in the spring bloom is kept in mind when drawing conclusions from the model results. We have assumed that at night $C$. finmarchicus reside at the depth where the food availability is largest. We compared the depth of the deep chlorophyll maximum from the model to those from data in 1995 (Fig. 3b). Both the model and the observations show that the chlorophyll maximum deepens immediately following the spring bloom. However, the observations show that during summer this depth is very variable, while the modelled depth becomes gradually shallower towards the end of July.
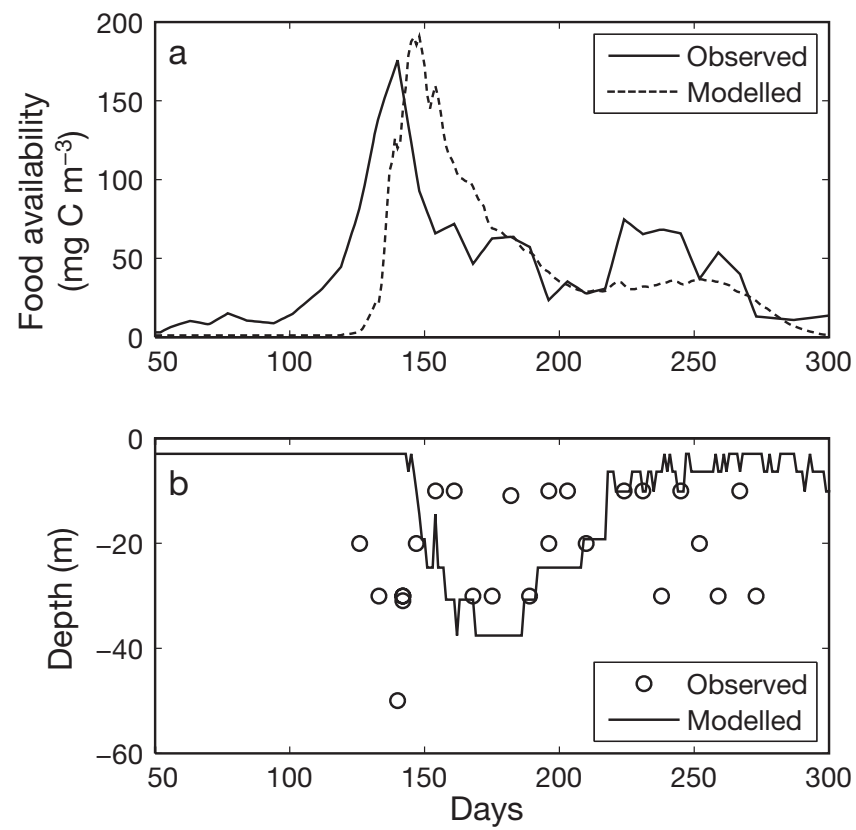

Fig. 3. (a) Estimates of carbon (converted from chlorophyll to units of carbon using $11 \mathrm{~g} \mathrm{~N} \mathrm{~g}^{-1} \mathrm{chl} a$ and $6.6 \mathrm{~mol} \mathrm{C} \mathrm{mol}^{-1} \mathrm{~N}$ ) based on data from Station M in 1995 (solid line) and the model-derived food availability at Station M (dashed line), both averaged over the upper $50 \mathrm{~m}$. The modelled spring bloom occurs later than in the observed data, although the magnitude is comparable. (b) Depth of maximum chlorophyll concentration based on observations from Station M (circles) and the modelled food availability (solid line). As for the carbon concentration, the timing of the deep chlorophyll maximum is delayed in the model results
In order to check the model performance we compared time series of Calanus finmarchicus from Ocean Weather Station $M\left(66^{\circ} \mathrm{N}, 2^{\circ} \mathrm{E}_{\text {; Fig. }}\right.$ ) from 1997 with results from the same location in the smallest model grid (Fig. 4). The only comprehensive data set available was from 1997; to allow more direct comparison with these data, an additional model run with atmospheric forcing and modelled food availability from 1997 and all other parameters as in WUD35 was performed. The data for Station $M$ were collected during the TASC (Trans-Atlantic Studies of Calanus finmarchicus) project (available from http://tasc.imr.no/tasc/ reserved/cruiseact/timeseries.htm). The intention was not to do a rigorous validation of the model, but to check that the model produced reasonable results. The peak of the $\mathrm{C} 1$ stage was about $10 \mathrm{~d}$ later in the model than in the data (Fig. 4); this was caused by the delay in the spring bloom in HYCOM-NORWECOM. The estimated peak abundance from the model was too large for the Copepodite Stages C1 and C2 and on the low side for the subsequent stages. The reason that the model results do not have any individuals of Stage C5 prior to the spring bloom is that the over-wintering individuals in the model are assumed to immediately moult to adults upon reaching the upper mixed layer. This was implemented to simplify the model.

Various stages of the seasonal progression in the reference run are illustrated in Fig. 5. On March 16 (Day 75), all individuals had exited diapause and the majority had reached the surface. The distribution was still similar to the overwintering distribution (Fig. 2), and very few of the individuals had yet been transported onto the shelf (Fig. 5a). In the present study we chose to consider the areas that are shallower than $500 \mathrm{~m}$ as shelf areas (the location of this isobath is indicated on Fig. 5). On May 10 (Day 130), some adults had been transported onto the shelf, particularly in the area of the Norwegian trench and the Halten Bank (Fig. 5b), but reproduction still had not started. A few weeks later, on June 4 (Day 155), the reproduction had started on the shelf (Fig. 5c). By midsummer (Day 170), there were almost no overwintering individuals left in the southern part of the domain and on the shelf, while reproduction was still taking place in the northern corner of the domain (Fig. 5d). At this time, some of the individuals had already started their downward migration towards the overwintering depth, but the majority of individuals remained at the surface.

\section{Simulation results}

Time series for nauplii and copepodites were generated by summing up the number of individuals at all depths over the inner model domain. Separate time 

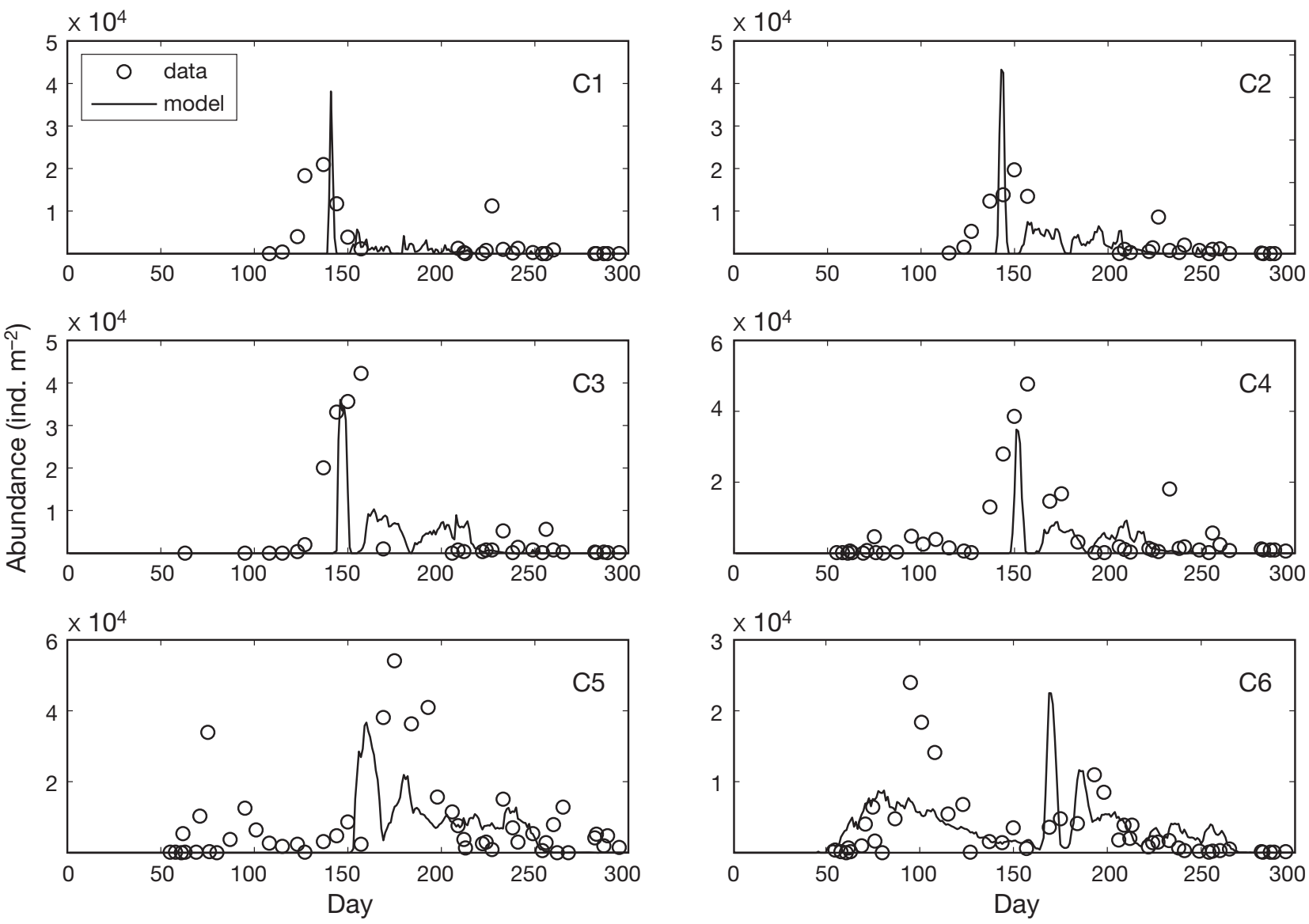

Fig. 4. Time series of different developmental stages of individuals per square metre in the upper $100 \mathrm{~m}$ of the water column from the inner model (solid line) and data from Station M in 1997 (circles). Station M is located at $66^{\circ} \mathrm{N}, 2^{\circ} \mathrm{E}_{\text {; }}$ the results from the model were averaged over an area of $1 \times 1^{\circ}$ with Station $M$ at the centre

series were calculated for the individuals residing on the shelf, but also here individuals at all depths were counted. The fat reserve that was left from the overwintering was used to produce eggs immediately upon reaching the surface (Fig. 6a), and the pre-bloom egg production decreased with increasing wake-up day. There was no pre-bloom production in the LESSFAT run. Due to food shortage, few of the eggs produced during the pre-bloom period developed into copepodites, and, in all the runs, the majority of first-generation copepodites occurred after the spring bloom had started (Fig. 6b). The total abundance of copepods was larger when the overwintering adults spent a shorter time at the surface prior to the spring bloom. When the food availability was spatially averaged, the spring bloom was less intense, but lasted longer (Fig. 7). The UNIFOOD run, therefore, had a higher total abundance of Calanus finmarchicus than the reference run (Fig. 6b), and this run also produced a second generation that was considerably larger than that in other runs. The maximum numbers of super-individuals in each run were 135 for WUD15, 147 for WUD35, 224 for WUD55, 50 for LESSFAT and 666 for UNIFOOD.

The number of copepodites on the shelf was dependent on both food availability and wake-up day, and the shelf nauplius abundance decreased with later wake-up day (Fig. 6c,d). There are 2 peaks in nauplius abundance on the shelf; one during pre-bloom production and one slightly smaller peak that coincides roughly with the onset of spring bloom in the model (Day 120). Observations of nauplii along the coast show that the nauplius maxima occur between Days 75 and 120 (Bjørke \& Rey 1991). For the recruitment of copepodites, it is clear that, for total abundance, it is favourable to have an earlier shelf spring bloom, but not favourable to have an early wake-up day, because the nauplii will then die from starvation. However, if the percentage of the shelf population relative to the total population is calculated, the runs with early wake-up days result in a higher percentage on the shelf (Fig. 6f). The UNIFOOD run resulted in a lower percentage of the total population on the shelf (Fig. 6f). 
a) March 16 (Day 75)

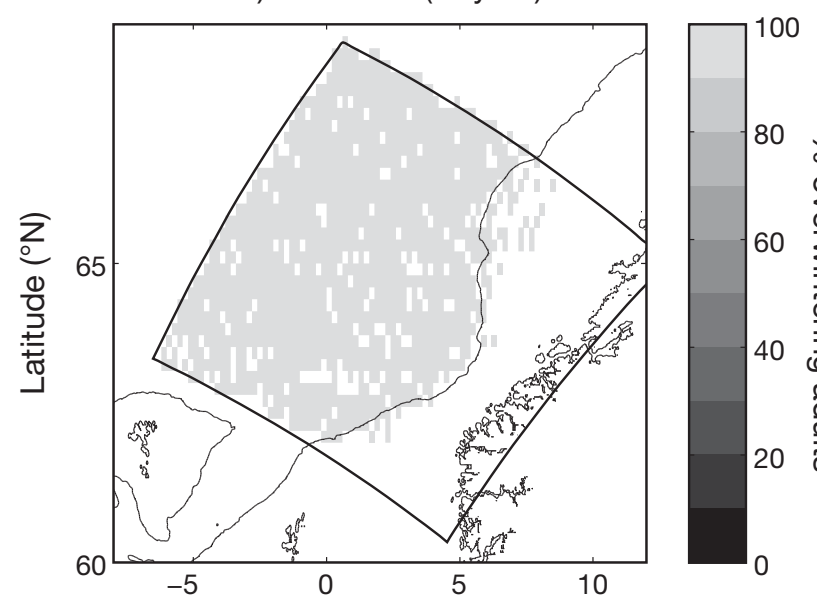

c) June 4 (Day 155)
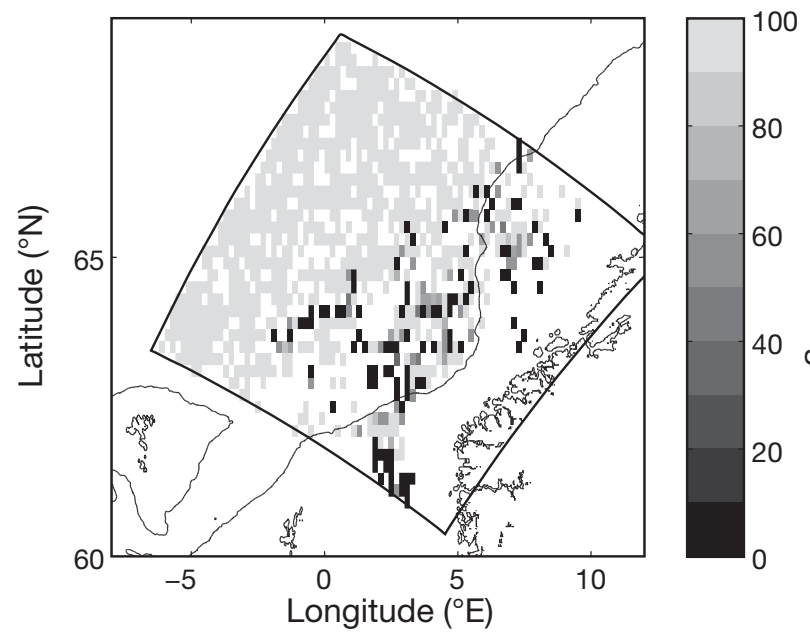

b) May 10 (Day 130)

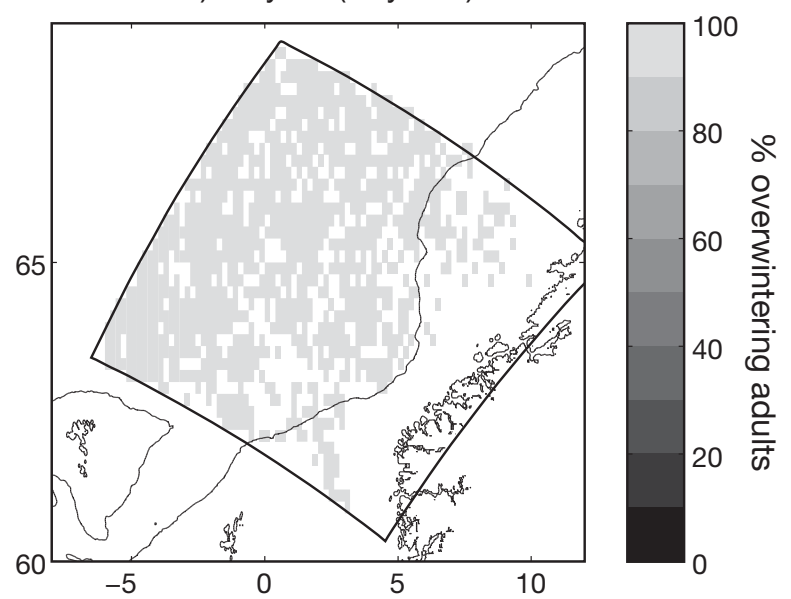

d) June 19 (Day 170)

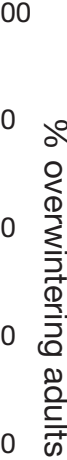

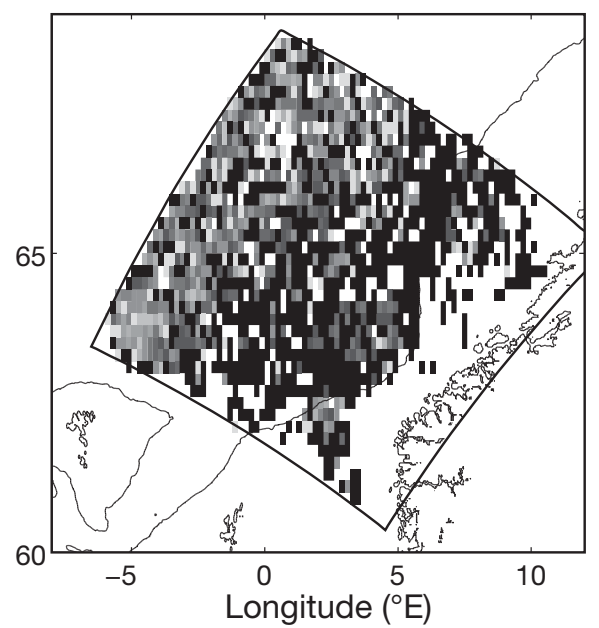

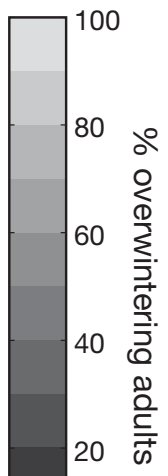

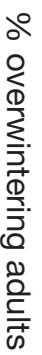

Fig. 5. Progression from the overwintering population to the new generation in spring. Grey-scale indicates the percentage of the total number of super-individuals that have overwintered. The distribution of super-individuals is shown when (a) they have just reached the surface (March 16, Day 75), (b) just before they started to reproduce on the shelf (May 10, Day 130), (c) the reproduction is advanced on the shelf (June 4, Day 155), and (d) the new generation dominates the numbers in the entire domain (June 19, Day 170). The solid line off the coastline indicates the $500 \mathrm{~m}$ isobath

We used the criteria that an individual must be outside the shelf break for at least $3 \mathrm{~d}$ and subsequently inside the shelf break for $>3 \mathrm{~d}$ in order to be counted as on-shelf transport. The shelf break was defined as the $500 \mathrm{~m}$ isobath. Very little cross-shelf transport occurred prior to the ascent to the surface (Fig. 8). The particles in the model were allowed to float in 3 dimensions, but, at depth, the currents tended to flow along the isobaths, and little cross-shelf transport occurred. The largest on-shelf transport values were in the late winter/early spring (Fig. 8), even if the total number of super-individuals was largest during the summer. Prior to Day 120, the on-shelf transport of Calanus finmarchicus occurred in pulses of about a week, and the onshelf transport values in the WUD55 and LESSFAT runs were much lower and qualitatively different than the on-shelf transport values in other runs (Fig. 8).

The temporal variability in the transport of particles across the shelf was related to the variability in the wind field. There was a good correspondence between westerly wind stress and transport of particles close to the surface $1 \mathrm{~d}$ later; the correlation (r) with nauplius transport was 0.39 , while the correlation with copepodite transport was small $(\mathrm{r}=+0.07, \mathrm{p}<0.01)$. All correlations were calculated with particles from all 5 simulations combined. There was also a correlation between nauplius transport and both south-westerly wind stress $(\mathrm{r}=+0.30, \mathrm{p}<0.01)$ and wind speed $(r=+0.27, p<0.01)$, both with the transport lagging the wind by $1 \mathrm{~d}$. The correlation with wind speed is pre- 

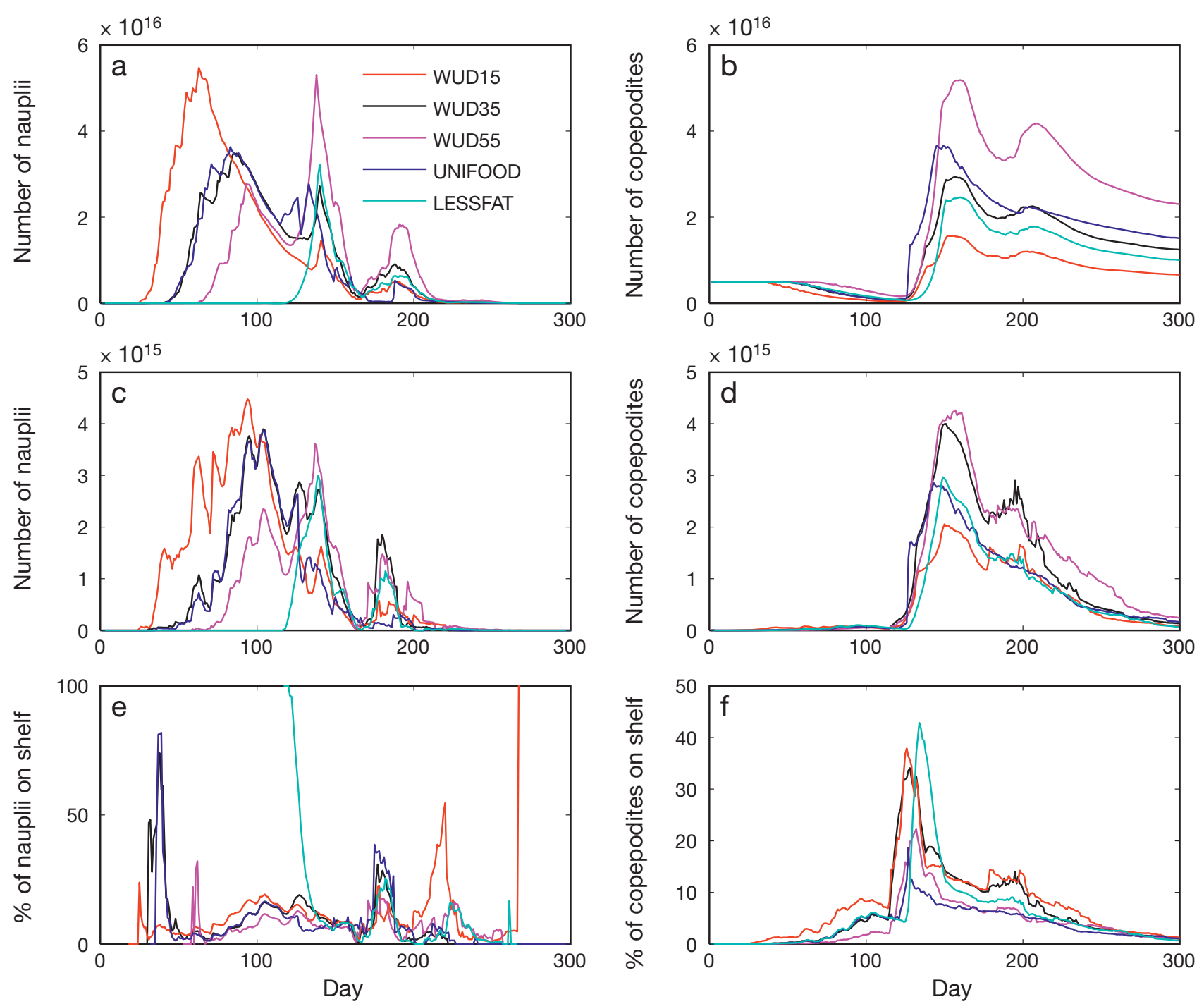

Fig. 6. Time series of total number of individuals, including individuals at all depths, in the 5 model runs (see Table 4). (a,b) Number of individuals in the whole model domain for (a) nauplii and (b) copepodites. (c,d) Number of individuals on the shelf for (c) nauplii and (d) copepodites. (e,f) Percentage of individuals on the shelf for (e) nauplii and (f) copepodites

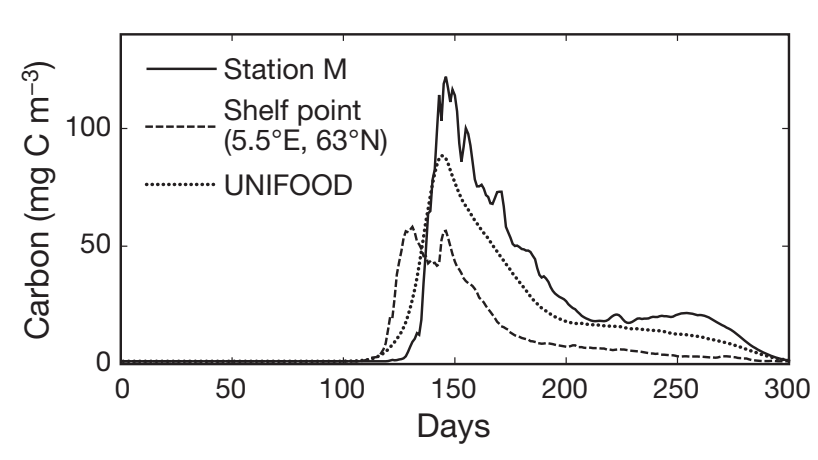

Fig. 7. Time series of the phytoplankton carbon concentration averaged over the upper $100 \mathrm{~m}$ of the water column at Station $\mathrm{M}$ (representing an open ocean point), at a shelf point $\left(63^{\circ} \mathrm{N}\right.$, $5.5^{\circ} \mathrm{E}$ ) and for the spatially averaged carbon concentration used in the UNIFOOD run sent because strong westerly winds are connected with the passing of storms, which bring strong winds, so these 2 variables are themselves correlated. When the westerly wind stress was multiplied by the number of individuals in the upper $100 \mathrm{~m}$, the resulting correlation with transport was even larger, and $67 \%$ of the transport of nauplii and $42 \%$ of the transport of copepodites could be explained in terms of this variable. The higher correlation for nauplii than copepods reflects that copepodites on average reside deeper in the water column than nauplii (Fig. 9).

The on-shelf transport of overwintering individuals decreased with later wake-up day (Fig. 10a). When the food availability and fat reserves were the same (WUD15, WUD35 and WUD55), the number of superindividuals produced on the shelf also decreased with 


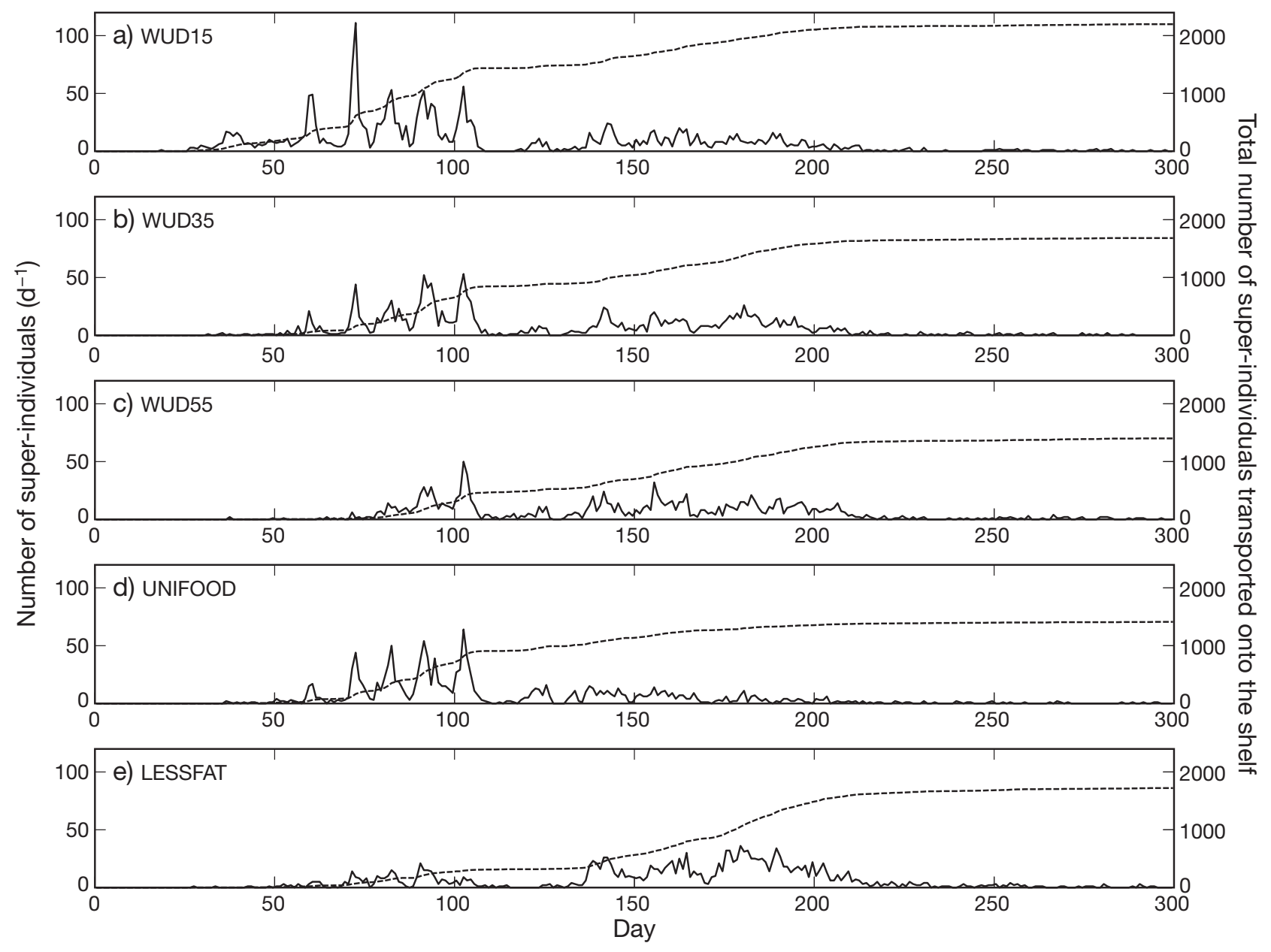

Fig. 8. Time series of transport of individuals onto the shelf (super-individuals $\mathrm{d}^{-1}$ ) in the 5 model runs (see Table 4). The left axis (solid line) shows the daily transport values and the right axis (dashed line) shows the cumulative sum of the daily transport values

later wake-up day, but the number of individuals increased (Fig. 10c). This is because with later wake-up day the number of individuals transported across the shelf break decreases, but the feeding conditions improve such that each super-individual can produce more eggs. The local reproduction on the shelf was largest in the LESSFAT run. Transport of first-generation individuals, both across the shelf break and from the outer to the inner model domain, decreased with later wake-up day. However, the biomass of the firstgeneration individuals that were transported onto the shelf increased with later wake-up day (Fig. 10b), which reflects the better feeding conditions off the shelf later in the spring. In the UNIFOOD run, individuals that were spawned off the shelf and subsequently transported onto the shelf were a larger source of shelf individuals than the local production on the shelf (Fig. 10a). The on-shelf transport was largest in the northern part of the domain (Fig. 11), while on the southern part of the shelf there is a large flux of indi- viduals from the outside model domain. The on-shelf transport appears to be connected to the topography (Fig. 11), particularly the Norwegian trench, and the deep trenches north and south of the Halten Bank are areas where many individuals were transported onto the shelf.

\section{DISCUSSION}

\section{Model performance}

We have used a model for the circulation in the Norwegian Sea together with an individual-based model for Calanus finmarchicus to simulate the annual cycle for this species in a small domain off the Norwegian coast. We found that large on-shelf transport values were connected with the periods of strong westerly winds associated with passing low-pressure systems. This wind-driven transport was particularly important for 

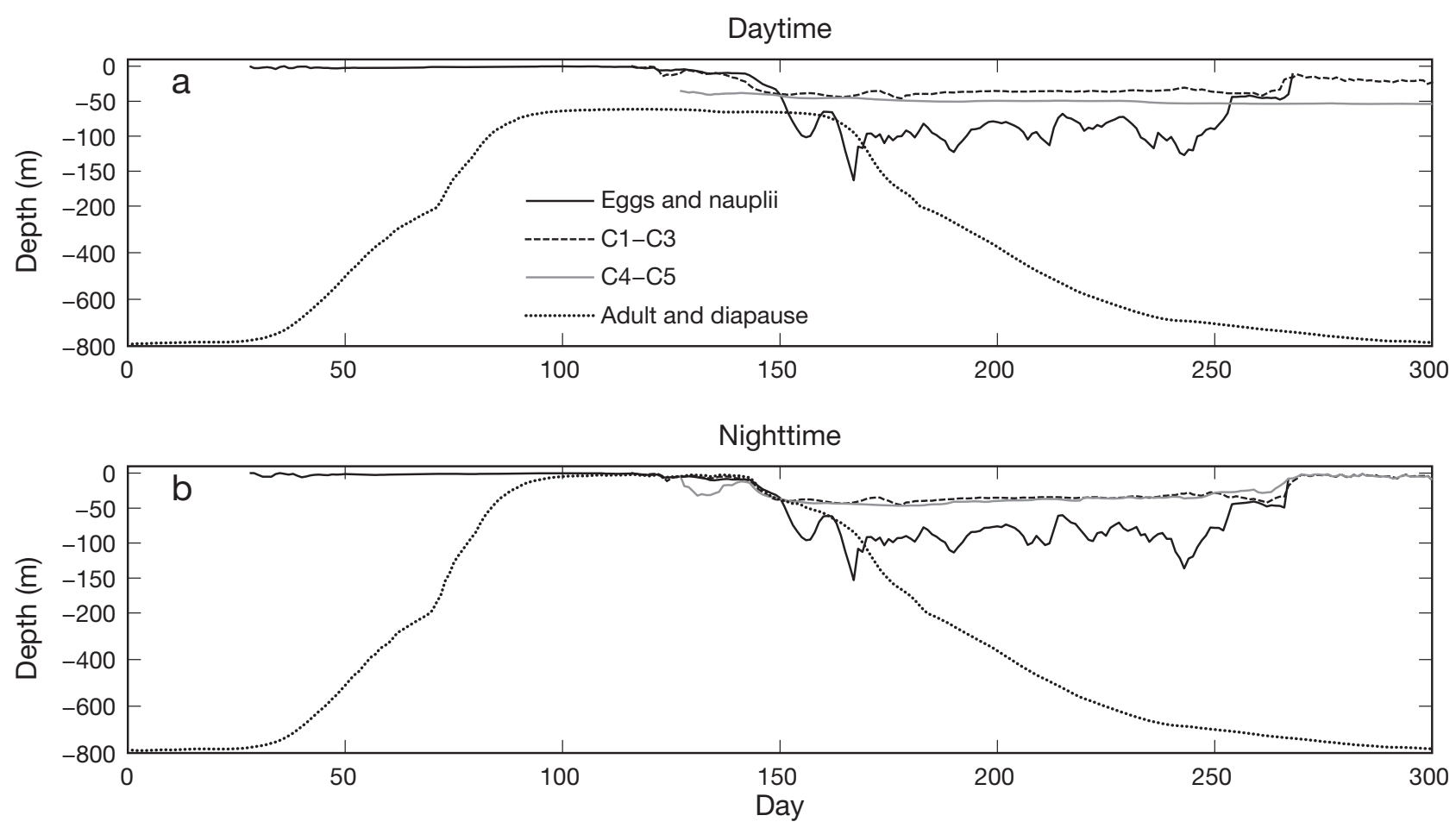

Fig. 9. The mean vertical position for different stages during (a) day and (b) night. Eggs and nauplii resided closer to the surface than the adults prior to Day 150. After this, the smallest individuals resided deeper than the copepods because eggs and nauplius Stages N1 and N2 sink when they are below the mixed layer. In this period, however, most of the recruitment had occurred and the overall number of eggs and nauplii was small

nauplii, which reside higher in the water column than copepodites during spring (Fig. 9). The size of the shelf population in spring was boosted by an early spring bloom on the shelf. This difference between the shelf and open ocean lasted until the end of August. We also found that when food was made available for a longer period, a larger second generation was produced.

The CFIBM performed reasonably well when compared to data from Ocean Weather Station M (Fig. 4), but the timing and magnitudes did not fully agree with the observed data. The discrepancy in the timing occurred because the spring bloom in NORWECOM was about 2 wk later than the observed spring bloom (Rey 2004). The peak abundance in the model compared well with the observed data, but the width of this peak is much narrower in the model (Fig. 4). The discrepancies between the observed and model-generated time series were consistent for all model runs. The timing of the spring bloom in the Norwegian Sea varies by about 1 mo inter-annually between Days 120 and 155 at Station $M$ (Rey 2004). Therefore, the runs we have performed best represent a year when the spring bloom is late (Fig. 7). Another source of inconsistency is that, in the model, it was assumed that only Stage C5 migrates down to diapause, but in reality the earlier stages can also enter diapause (Hirche 1996a, Heath et al. 2004).
This can be seen from the early occurrences of C4 stages at Station $\mathrm{M}$ in spring (Fig. 4). The shallowest areas in the model domain did not become populated by Calanus finmarchicus (Fig. 5), partly because individuals tend to get 'stranded' and killed in the very shallow areas. This is an artificial source of mortality in the model code that needs to be addressed in future versions of the HYCOM model. The food availability was also underestimated close to the coast in the NORWECOM model.

The pre-bloom spawning in the model did not result in much recruitment of copepodite stages. The first peak of C1 coincided roughly with the spring bloom in the model, and this was consistent with the timing of the C1 peak from observations (Melle et al. 2004). An explanation for the starvation of the pre-bloom nauplii could be that the pre-bloom phytoplankton production in the model is too low (Fig. 3) or that both the late stages of nauplii and adult individuals can feed on other food particles than phytoplankton during this time. It is likely that Calanus finmarchicus feed on detritus particles (Carlotti \& Radach 1996) and microzooplankton (Ohman \& Runge 1994) when phytoplankton is limited.

Because the food availability dictated the recruitment in the model, the timing of the maximum number of copepodites both on the shelf and in the open ocean 

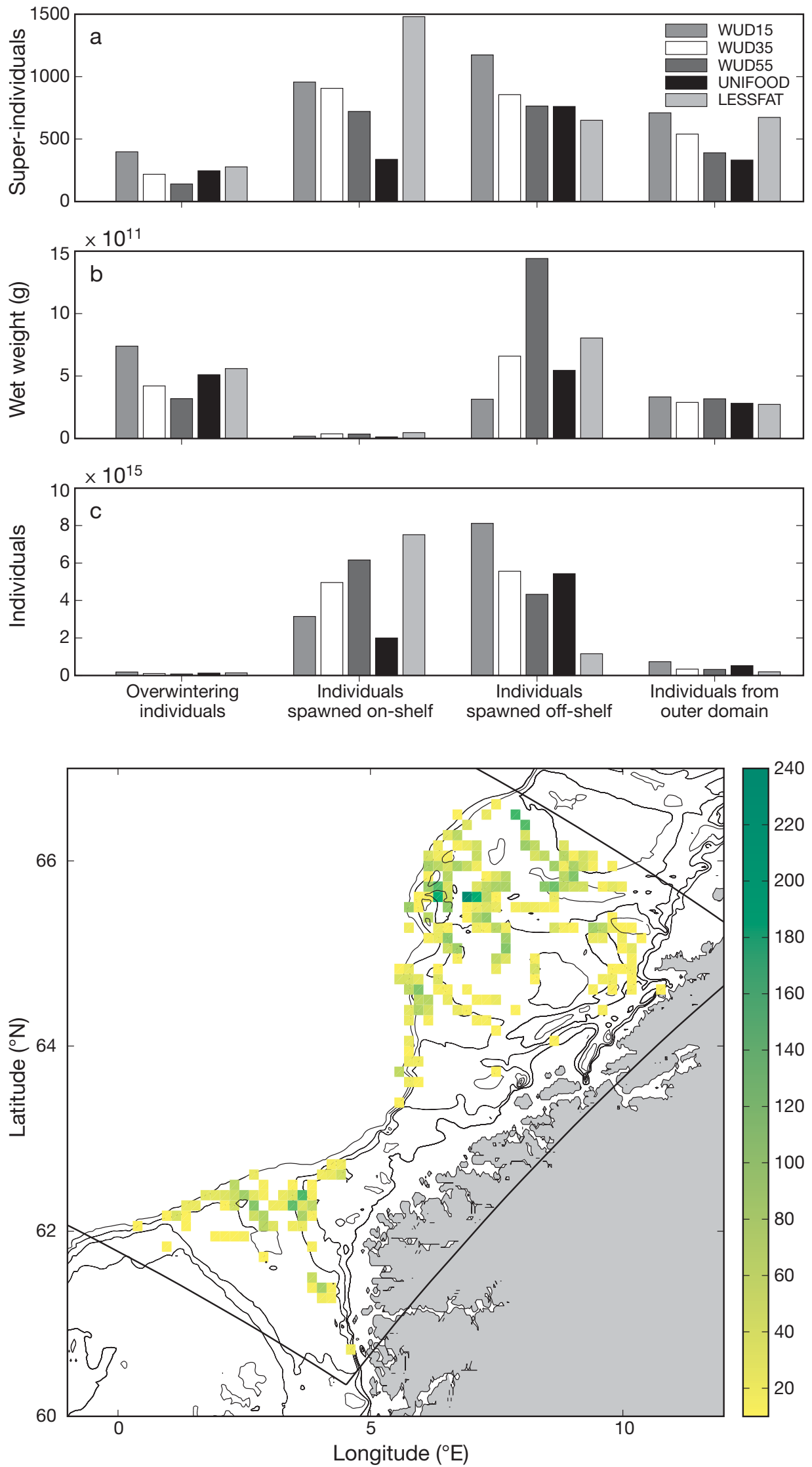

Fig. 10. Shelf recruitment from 4 different sources ( $x$-axis labels) in the 5 model runs (see Table 4). Source 1 was the number of overwintering super-individuals that are transported onto the shelf in the spring. Source 2 was the number of super-individuals that are produced on the shelf in the spring and Source 3 was the number of super-individuals that were produced off-shelf and subsequently transported onto the shelf. Source 4 was the number of super-individuals that entered the shelf from the outside domain. Shelf recruitment is shown in terms of (a) number of superindividuals, (b) units of biomass and (c) number of individuals
Fig. 11. Shelf entry positions for all 5 model runs together. The colour indicates the number of super-individuals that crossed a specific isobath at that location. The cross-isobath transport is shown for the $500,450,400,350$ and $300 \mathrm{~m}$ isobaths 
coincided in all runs, except for the UNIFOOD run, where the maximum number of copepodites was earlier. The total population size varied between runs, but the percentage of individuals on the shelf was considerably different only in the UNIFOOD and WUD55 runs. The UNIFOOD run did not have an earlier spring bloom on the shelf; this affected the shelf abundance from spring and throughout the summer. The WUD55 run had a low shelf population because of low transport of adults onto the shelf. The reason for this is that these individuals arrive at the surface so late that they miss some of the large transport events that occurred prior to their arrival in the surface waters (Fig. 8). In summary, having an early wake-up day had a positive effect on the transport of individuals across the shelf, but a negative effect on the survival of the offspring.

Comparing the on-shelf transport from Day 1 to 180 in the $16 \mathrm{~km}$ model versus the $4.5 \mathrm{~km}$ model (for the standard run), we find that the on-shore transport in the high-resolution model is $56 \%$ higher than in the $16 \mathrm{~km}$ model. If Ekman drift was the only process at work, the difference between the 2 models should not be that large. Correlation analysis showed that the onshelf transport in the coarse model was also highly correlated to westerly wind for nauplii $\left(\mathrm{r}^{2}=0.69\right)$, while $\mathrm{r}^{2}$ was only 0.11 for copepodites (compare to $r^{2}=0.42$ in the $4.5 \mathrm{~km}$ model). The $4.5 \mathrm{~km}$ resolution model allows for much more mesoscale variability than does the $16 \mathrm{~km}$ model, and eddies and mesoscale variability can potentially act to amplify the wind-driven transport. Further investigation is necessary to resolve this.

When using super-individuals there is always the question of how many super-individuals to use. A test run in which the initial number of individuals was increased by $150 \%$ was performed in the outer model domain and compared to the original run. The 2 runs were almost identical with regards to timing and maximum and minimum magnitudes. The difference in the mean number of individuals in the entire model domain is $0.5 \%$ for nauplii and $0.6 \%$ for copepodites; on the shelf, the difference is $3 \%$ for nauplii and $0.2 \%$ for copepodites; and, at Station $M$, the difference is $5.9 \%$ for nauplii and $0.1 \%$ for copepodites. In comparison, the difference at Station $M$ between the mean number of copepods in the reference run and the other 4 model experiments presented in this paper vary between 23 and $50 \%$. This indicates that the model results are robust with the present number of super-individuals.

\section{On-shelf transport of Calanus finmarchicus}

The on-shelf transport of nauplii was large early in the year, but, because so few of these survived, it was the transport of overwintering adults that determined the shelf abundance prior to mid-summer. There was more on-shelf transport of overwintering individuals when they surfaced early because they had a longer period to be transported onto the shelf and the transport was largest in the winter/early spring. After midsummer, on-shelf transport of first-generation individuals became more important for the shelf abundance than the local production by overwintering individuals. The importance of local recruitment on the shelf versus transport of first-generation individuals onto the shelf varied between the different runs (Fig. 10). For the reference run and the 2 runs for which the wake-up day was altered, the contribution, in number of superindividuals, was roughly equal, but the contribution from locally spawned super-individuals was a little smaller for the WUD15 run. In the UNIFOOD run about twice as many individuals were spawned off the shelf than locally, while in the LESSFAT run the largest contribution to the shelf population was from the individuals spawned on the shelf. Because the relative contributions were so sensitive to growth conditions, from these model results it is difficult to say which factor is most important.

The episodes of high on-shelf transport (Fig. 8) were always associated with strong westerly wind stress. Nauplius transport had a higher correlation ( $\mathrm{r}=0.39$ ) with westerly wind stress than did copepodite transport $(r=0.07)$, because they resided closer to the surface. The copepodites performed diurnal migration and therefore resided deeper in the water column, on average, than did nauplii (Fig. 9). This is the reason why the on-shelf transport values in the 2 runs that had little and no pre-bloom spawning (WUD55 and LESSFAT), i.e. few nauplii present prior to spring bloom, were qualitatively different than the transport values in the other runs (Fig. 8). The on-shelf transport of nauplii lagged by $1 \mathrm{~d}$ behind the westerly wind stress multiplied by the number of individuals at the surface, with a correlation of $\mathrm{r}^{2}=0.67$. There was also a good correlation between wind speed multiplied by the number of individuals at the surface and on-shelf transport, both for nauplii $\left(\mathrm{r}^{2}=0.49\right)$ and copepodites $\left(\mathrm{r}^{2}=0.47\right)$. The westerly wind will set up an Ekman transport to the south, but this is the average transport over the Ekman layer. The nauplii, however, reside in quite shallow waters, at the depth of the maximum food concentration, and their transport direction will be closer to the wind direction than the depth-integrated transport. For example, the surface transport according to linear theory is $45^{\circ}$ to the direction of the wind. Hence, the westerly wind causes an on-shore transport of shallow individuals, and the $1 \mathrm{~d}$ lag in transport occurs because it takes about $1 \mathrm{~d}$ for the ocean currents to respond to the rotation of the earth and set up the Ekman transport. 


\section{Shelf entry routes}

The entry routes taken by the Calanus finmarchicus were related to bathymetry. In particular, the deep trenches around Halten Bank and the Norwegian trench were favoured places to enter the Norwegian shelf (Fig. 11). The northern North Sea was mainly populated from the outer model domain, with individuals originating from the area around the FaeroeShetland channel, which is in line with previous work (Heath et al. 1999). The actual mechanism by which the trenches affect shelf recruitment is still unclear. Irregularities in the shelf topography, such as canyons, have been proposed to influence cross-shelf transport (Haidvogel 2005). To investigate the influence of the bathymetry, a numerical experiment was performed in which the bathymetry in the $4.5 \mathrm{~km}$ model was smoothed so that it resembled the topography of the $16 \mathrm{~km}$ model. There was no difference in the transport of $C$. finmarchicus between the two $4.5 \mathrm{~km}$ runs with different bathymetry features in the first half of the year. For copepodites, the transport across the shelf is smaller in the model with smoothed topography, leading to a slightly lower shelf population at the end of summer in this run. However, in the $16 \mathrm{~km}$ model, the cross-shelf transport is smaller in the first half of the year and larger in the second half of the year compared to the reference run. It is therefore unlikely that there were features in the bathymetry which influenced transport values that were not resolved in the $16 \mathrm{~km}$ model. We do not exclude the possibility that bottom topography can influence the cross-shelf exchange, but, for the spatial scales resolved in these 2 models, it does not seem to be important. Previous studies have shown that a canyon induces cross-isobath flows only when it is narrow compared to the Rossby radius (Klinck 1988). Neither of the models presented here resolves the topography at this scale. A more recent study (Klinck 1996) showed that canyon-induced cross-shelf flow is sensitive to the direction of alongshore flow. The flow direction along the Norwegian coast (northward, with the coast on the right) is that inducing the least cross-isobath flow. The physical mechanisms governing the cross-shelf transport of particle and water masses in this area will be the subject of future research.

\section{Calanus finmarchicus transport and herring recruitment}

The frequency of low-pressure systems in the Norwegian Sea changes interannually because storm tracks shift north or south depending on the North Atlantic Oscillation (Hurrell 1995). Because the on- shelf transport of $C$. finmarchicus was dependent on strong westerly winds, which occur most frequently during the passage of storms, we expect that there is an interannual variability in the shelf recruitment of $C$. finmarchicus. Because copepod nauplii are the main prey for small herring larvae (Bjørke 1971), this interannual variability influences the growth conditions for herring larvae. Herring eggs typically start hatching in the middle of March (Bjørke \& Rey 1991), and the interannual variability in the day when $50 \%$ of the eggs have hatched is about 1 mo (Husebø et al. 2009). In 1995, 50\% hatching was estimated to occur on April 5 , which is rather late compared to in some other years. Superficially, this corresponds well with the peak period in the transport of $C$. finmarchicus super-individuals onto the shelf (Fig. 8). Sætre et al. (2002) found that 0 -group herring abundance was positively correlated with the number of occurrences of high wind speed along the coast. They attributed the increased recruitment to increased feeding efficiency as a result of more turbulence in the water column. It is possible that the increased transport of $C$. finmarchicus onto the shelf is also a contributing factor for the survival of larvae and growth of 0 -group herring. An extension of the present work to cover several years would be very interesting in this respect and could shed further light on the considerable recruitment variation in the NSS herring stock.

Acknowledgements. We thank Francisco Rey for access to the chlorophyll time series from Station M and the TASC project for the zooplankton data. A.S. and C.H. thank T. Mohn, C/O Frank Mohn AS for financial support and the NOTUR project for grant of CPU hours. G.H. thanks the Research Council of Norway for financial support through the INFERNO project.

\section{LITERATURE CITED}

Backhaus JO, Harms IH, Krause M, Heath MR (1994) An hypothesis concerning the space-time succession of Calanus finmarchicus in the northern North Sea. ICES J Mar Sci 51:169-180

Bagøien E, Kaartvedt S, Aksnes DL, Eiane K (2001) Vertical distribution and mortality of overwintering Calanus. Limnol Oceanogr 46:1494-1510

Björk G, Gustafsson BG, Stigebrandt A (2001) Upper layer circulation of the nordic seas as inferred from the spatial distribution of heat and freshwater content and potential energy. Polar Res 20:161-168

Bjørke H (1971) The food of herring larvae of Norwegian spring spawners. Rapp P-V Réun Cons Int Explor Mer 160: 101-103

Bjørke H, Rey L (1991) Sildeklekking og næringstilbud utenfor Møre i 1987-1990. Havforskningsinstituttets egg og larveprogem (HELP), Institute of Marine Research, Bergen

Bleck R (2002) An oceanic general circulation model framed in hybrid isopycnic-Cartesian coordinates. Ocean Model $4: 55-88$ 
Campbell RG, Wagner MM, Teegarden GJ, Boudreau CA, Durbin EG (2001) Growth and development rates of the copepod Calanus finmarchicus reared in the laboratory. Mar Ecol Prog Ser 221:161-183

Carlotti F, Radach G (1996) Seasonal dynamics of phytoplankton and Calanus finmarchicus in the North Sea as revealed by a coupled one-dimensional model. Limnol Oceanogr 41:522-539

Carlotti F, Wolf KU (1998) A Lagrangian ensemble model of Calanus finmarchicus coupled with a 1-D ecosystem model. Fish Oceanogr 7:191-204

- Chambers RC (1993) Phenotypic variability in fish populations and its representation in individual-based models. Trans Am Fish Soc 122:404-414

Conkright ME, Levitus S, O'Brien T, Boyer TP and others (1998) World Ocean Database 1998: documentation and quality control. National Oceanographic Data Center, Silver Spring, MD

Cushing DH (1990) Plankton production and year-class strength in fish populations - an update of the match mismatch hypothesis. Adv Mar Biol 26:249-293

Dai A, Trenberth KE (2002) Estimates of freshwater discharge from continents: latitudinal and seasonal variations. J Hydrometeorol 3:660-668

Dale T, Kaartvedt S (2000) Diel patterns in stage-specific vertical migration of Calanus finmarchicus in habitats with midnight sun. ICES J Mar Sci 57:1800-1818

Drange H, Simonsen K (1996) Formulation of air-sea fluxes in the ESOP2 version of MICOM. Nansen Environmental and Remote Sensing Center, Bergen

Dumenil L, Isele K, Liebscher HJ, Schroder U, Schumacher M, Wilke K (1993) Discharge data from 50 selected rivers for GCM validation. Max-Planck-Institut für Meteorologie, Hamburg

Edvardsen A, Pedersen JM, Slagstad D, Semenova T, Timonin A (2006) Distribution of overwintering Calanus in the North Norwegian Sea. Ocean Sci 2:87-96

Ellertsen B, Fossum P, Solemdal P, Sundby S (1989) Relation between temperature and survival of eggs and first-feeding larvae of northeast Arctic cod (Gadus morhua L.). Rapp P-V Réun Cons Int Explor Mer 191:209-219

Fiksen O (2000) The adaptive timing of diapause - a search for evolutionarily robust strategies in Calanus finmarchicus. ICES J Mar Sci 57:1825-1833

Garraffo ZD, Mariano AJ, Griffa A, Veneziani C, Chassignet EP (2001) Lagrangian data in a high-resolution numerical simulation of the North Atlantic. I. Comparison with in situ drifter data. J Mar Syst 29:157-176

Haidvogel DB (2005) Cross-shelf exchange driven by oscillatory barotropic currents at an idealized coastal canyon. J Phys Oceanogr 35:1054-1067

> Halvorsen E, Tande KS, Edvardsen A, Slagstad D, Pedersen OP (2003) Habitat selection of overwintering Calanus finmarchicus in the NE Norwegian Sea and shelf waters off northern Norway in 2000-02. Fish Oceanogr 12:339-351

Hansen B, Østerhus S (2000) North Atlantic-Nordic seas exchanges. Prog Oceanogr 45:109-208

Heath MR (1999) The ascent migration of Calanus finmarchicus from overwintering depths in the Faroe-Shetland Channel. Fish Oceanogr 8:84-99

Heath MR, Backhaus JO, Richardson K, McKenzie E and others (1999) Climate fluctuations and the spring invasion of the North Sea by Calanus finmarchicus. Fish Oceanogr 8: 163-176

Heath MR, Fraser JG, Gislason A, Hay SJ, Jonasdottir SH, Richardson K (2000) Winter distribution of Calanus finmarchicus in the Northeast Atlantic. ICES J Mar Sci 57:
$1628-1635$

> Heath MR, Boyle PR, Gislason A, Gurney WSC and others (2004) Comparative ecology of overwintering Calanus finmarchicus in the northern North Atlantic, and implications for life-cycle patterns. ICES J Mar Sci 61:698-708

Hirche HJ (1996a) Diapause in the marine copepod, Calanus finmarchicus - a review. Ophelia 44:129-143

Hirche HJ (1996b) The reproductive biology of the marine copepod Calanus finmarchicus-a review. Ophelia 44: $111-128$

> Hunke EC, Dukowicz JK (1997) An elastic-viscous-plastic model for sea ice dynamics. J Phys Oceanogr 27:1849-1867

Hurrell JW (1995) Decadal trends in the North Atlantic Oscillation: regional temperatures and precipitation. Science 269:676-679

Huse G (2001) Modelling habitat choice in fish using adapted random walk. Sarsia 86:477-483

Huse G (2005) Artificial evolution of Calanus' life history strategies under different predation levels. GLOBEC Newsl 11:19

> Huse G, Strand E, Giske J (1999) Implementing behaviour in individual-based models using neural networks and genetic algorithms. Evol Ecol 13:469-483

Husebø Å, Stenevik EK, Slotte A, Fossum P and others (2009) Effects of hatching time on year-class strength in Norwegian spring-spawning herring (Clupea harengus). ICES J Mar Sci 66 doi:10.1093/icesjms/fsp150

Irigoien X, Titelman J, Harris RP, Harbour D, Castellani C (2003) Feeding of Calanus finmarchicus nauplii in the Irminger Sea. Mar Ecol Prog Ser 262:193-200

Klinck JM (1988) The influence of a narrow transverse canyon on initially geostrophic flow. J Geophys Res 93:509-515

Klinck JM (1996) Circulation near submarine canyons: a modeling study. J Geophys Res 101:1211-1223

Lynch DR, Gentleman WC, McGillicuddy DJ Jr, Davis CS (1998) Biological/physical simulations of Calanus finmarchicus population dynamics in the Gulf of Maine. Mar Ecol Prog Ser 169:189-210

Melle W, Ellertsen B, Skjoldal HR (2004) Zooplankton: the link to higher trophic levels. In: Skjoldal HR (ed) The Norwegian Sea ecosystem. Tapir Academic Press, Trondheim, p 137-202

Meyer-Harms B, Irigoien X, Head R, Harris R (1999) Selective feeding on natural phytoplankton by Calanus finmarchicus before, during, and after the 1997 spring bloom in the Norwegian Sea. Limnol Oceanogr 44:154-165

> Niehoff B, Klenke U, Hirche HJ, Irigoien X, Head R, Harris R (1999) A high frequency time series at Weathership $M$, Norwegian Sea, during the 1997 spring bloom: the reproductive biology of Calanus finmarchicus. Mar Ecol Prog Ser 176:81-92

Ohman MD, Runge JA (1994) Sustained fecundity when phytoplankton resources are in short supply-omnivory by Calanus finmarchicus in the Gulf of St. Lawrence. Limnol Oceanogr 39:21-36

> Ohman MD, Eiane K, Durbin EG, Runge JA, Hirche HJ (2004) A comparative study of Calanus finmarchicus mortality patterns at five localities in the North Atlantic. ICES J Mar Sci 61:687-697

Orvik KA, Skagseth $\varnothing$, Mork M (2001) Atlantic inflow to the Nordic Seas: current structure and volume fluxes from moored current meters, VM-ADCP and SeaSoar-CTD observations, 1995-1999. Deep-Sea Res I 48:937-957

Rey F (2004) Phytoplankton: the grass of the sea. In: Skjoldal HR (ed) The Norwegian Sea ecosystem. Tapir Academic Press, Trondheim, p 97-136

> Sætre R, Toresen R, Anker-Nilssen T (2002) Factors affecting the recruitment variability of the Norwegian spring- 
spawning herring (Clupea harengus L.). ICES J Mar Sci 59:725-736

Scheffer M, Baveco JM, Deangelis DL, Rose KA, Vannes EH (1995) Super-individuals a simple solution for modeling large populations on an individual basis. Ecol Model 80: $161-170$

Skogen M, Søiland H (1998) A user's guide to NORWECOM v2.0. The NORWegian ECOlogical Model system. Institute of Marine Research, Bergen

Skogen MD, Svendsen E, Berntsen J, Aksnes D, Ulvestad KB (1995) Modeling the primary production in the North Sea using a coupled 3-dimensional physical-chemicalbiological ocean model. Estuar Coast Shelf Sci 41: 545-565

Slagstad D, Tande KS (1996) The importance of seasonal vertical migration in across shelf transport of Calanus finmarchicus. Ophelia 44:189-205

Speirs DC, Gurney WSC, Heath MR, Wood SN (2005) Modelling the basin-scale demography of Calanus finmarchicus in the north-east Atlantic. Fish Oceanogr 14:333-358

Stenevik EK, Melle W, Gaard E, Gislason A, Broms CTA, Prokopchuk I, Ellertsen B (2007) Egg production of Calanus finmarchicus - a basin-scale study. Deep-Sea Res II 54:2672-2685

Sundby S (1984) Influence of bottom topography on the circu-

Editorial responsibility: Alejandro Gallego,

Aberdeen, UK lation at the continental shelf off northern Norway. Fiskeridir Skr Ser Havunders 17:501-519

Sundby S (2000) Recruitment of Atlantic cod stocks in relation to temperature and advection of copepod populations. Sarsia 85:277-298

Teague WJ, Carron MJ, Hogan PJ (1990) A comparison between the Generalized Digital Environmental Model and Levitus climatologies. J Geophys Res 95:7167-7183

Toresen R, Østvedt OJ (2000) Variation in abundance of Norwegian spring-spawning herring (Clupea harengus, Clupeidae) throughout the 20th century and the influence of climatic fluctuations. Fish Fish 1:231-256

> Torgersen T, Huse G (2005) Variability in retention of Calanus finmarchicus in the Nordic seas. ICES J Mar Sci 62: 1301-1309

Uppala SM, Kallberg PW, Simmons AJ, Andrae U and others (2005) The ERA-40 re-analysis. Q J R Meteorol Soc 131: 2961-3012

> Vikebø F, Sundby S, Adlandsvik B, Fiksen O (2005) The combined effect of transport and temperature on distribution and growth of larvae and pelagic juveniles of ArctoNorwegian cod. ICES J Mar Sci 62:1375-1386

- Visser AW, Jonasdottir SH (1999) Lipids, buoyancy and the seasonal vertical migration of Calanus finmarchicus. Fish Oceanogr 8:100-106

Submitted: January 24, 2008; Accepted: April 15, 2009 Proofs received from author(s): June 26, 2009 